\title{
Ethnic Militias and Democratic Governance in
} Nigeria

\author{
N. H Iwu, PhD, B. O Ajisafe \\ Political Science and Public Administration Department, Adekunle Ajasin University, Akungba-Akoko, Nigeria
}

\begin{abstract}
Uneven space that characterized the political space during the decades of military rule opened up at the triumph of democracy in 1999 offering minority ethnic groups initially emasculated under dominant ethnic group(s) opportunities to agitate for inclusion and prominence in Nigerian politics. Saturating the political space and contesting ferociously against one another, the Nigerian state is enmeshed in an almost state of nature where the institutional mechanism for dialogue and administration has plummeted. While the agitators find justification on the principle of democracy that creates for equity, fairness, open competition for political offices, the assurance of such remains illusory, thereby offering anchor for the emergence of ethnic militias to contest the closed space against minority groups. Certain questions emerge: why are ethnic militias used as an instrument of bargaining in Nigeria? What type of demands do they make? What are their implications on democratic governance in Nigeria? Drawing from secondary data and theory of state fragility the papers argues that responding to demands from ethnic militias creates more problems as it spurs a circle of agitations that weakens institutions of governance. Therefore, the paper advocates for robust civil societies to contain the state's drift towards unaccountable governance that breeds sub-groups agitations.
\end{abstract}

Keywords: ethnic militias, good governance, democratization, insecurity, electoral democracy

\section{INTRODUCTION}

$\mathrm{N}$ igerian society is a sociological aggregate consisting of distinct cultural groups and institutions which interact and make claims on the resources of the state (Onwuejeogwu 1972, Otite, 2000). Promises of open competition and equality offered in democracy create justifiable reasons for engaging the state that fails to meet its basic obligations. The republican liberalists assume that liberal democracies would be more peaceful (Kant 1992). While the assumption may be confirmed in international relations, ethnic militias are heating the national politics that adversely affect global peace. Groups anchoring on their diverse cultures struggle in contestation to break the monopoly of power by one cultural group (Smith, 1965). The emergence of the Igbo state union, Ogoja state union, Egbe Omo Oduduwa, and Arewa peoples' Congress (APC) as a response to challenging disparity witnessed under the colonial government in Nigeria (Coleman 1986, Osaghae, 1994, Otite, 2000). Postcolonial Nigeria has seen more ethnic unions which have taken on the part of militancy often rationalized as characteristic of civil society competing for space in a closed environment engineered by few privileged groups (Lijphart 1977, Nnoli 1978, 1998, Varshney 2002,
Osaghae 1998, Sesay et al 2003, Bob 2011, Gowon and Effiong 2001, Isumonah and Gaskia 2001,).

The militant approach adopted by these ethnic unions resulted in the loss of their original cultural focus to the defense of the group's economic interest through a calculated attack on Nigeria and other ethnic groups within its regional dominance. The emergence of Oodua Peoples' Congress (OPC), Bakassi Boys, Egbesu Boys, and Arewa Youths Assembly (AYA), etc as ethnic militias are seen as a response to the perceived marginalization by the dominant group or region. The forms of interactions by these ethnic militias are instrumental to the "heat" experienced in national politics, impinging on universalism pursued by most advanced democratic states. Conventional ideas on militias groups are such that links poverty to the emergence of ethnic militias or terrorists, which according to Coggins (2015) does not produce sufficient evidence. Coggins argues that factors like violations of political rights, institutional inefficacy, and corruption have increased tendencies to produced terror groups. Seeing poverty as prime nexus moving an individual into getting involved in a militia or terrorist activities may have influenced scholars who focused on the individual level as the basis for analysis (Abrahms 2004, Bloom 2005, Horowitz 2010). The approach has hyped state failure and level of poverty as a causal factor for the emergence of militias or terrorist groups. State fragility resulting in institutional weakness, therefore, creates avenues for mobilization of vulnerable groups by the politicians or the government that often produces terrorism or ethnic militias in Africa. 'Powerful' politicians having territorial control over electoral success are measured against their ability to command the youths in their locality into action either to destroy their local opponents or to counter the influence of any politicians from any other ethnic group. Also, the government often compromises its role as the sole monopoly of the use of violence within a given territory to enlist the services of ethnic militias in the governance structure. In this context, political scientists with bias in comparative politics have responded by focusing scholarship towards understanding and explaining the mutually exclusive interests and the dynamics raised by these non-state actors. Thus, the study of the political process is broadened to include how these non-state associations influence decision-making, internal dynamics, and the structuration of political power. In the context for which state power is appropriated by some powerful members of the society, those who double as members of these ethnic militias, often use their positions to 
influence decisions at the national politics. Finer (1966: 2526) notes that the private association's hope of success in its competition with other groups is maximized if the full power of the state as mediated through government is put behind it. This paper is written in four parts. The first is the introduction. The second part provides an overview of ethnic militias as a phenomenon; the third part engages ethnic militias in the context of democratic governance in Nigeria. The fourth part concludes the discussion.

\section{ETHNIC MILITIAS AS A PHENOMENON IN NIGERIA}

A popular notion about ethnic militias in Nigeria is that it is an outlaw. This is a simplistic appellation because they combine in their actions instruments of bargaining that negotiate with the national government on resources allocations on behalf of their ethnic unions. However, Sesay, Ukeje et al (2003: 23) define ethnic militias as irregular or paramilitary groups usually made up of civilians who might have received some form of non-formalized or unofficial military training and are armed with small arms and light weapons. The military training was not characteristic of their early formation as they took off as a socio-cultural organization. Thecontemporaryclaim to historical link with their foremost ethnic groups in the formative stages of these unions was created around the consciousness of cultural separateness from other ethnic groups. Egbe Omo Oduduwa the foremost Yoruba socio-cultural organization was formed in 1945 as a response to colonial politics that created regional politics (Niven 1958). Pan-Ibo movement was formed in 1935 in Lagos to celebrate the homecoming of Sir Francis Ibiam, the Ibo medical doctor after his successful study abroad, and also to respond to the welfare of members and for the uniform's voice on common issues and most importantly educational advancement (Coleman, 1986). Southern Minority groups like Edo National Union, Ibibio State Union, and Izon State union were formed in response to their particular needs as contrasted from other unions.

In 1943, two young northerners; Mallams Sa'ad Zungur and Aminu Kano organized the Bauchi General Improvement Union (BGIU). Zungur had patiently observed nationalist activity in the south while he was a student at Yaba Higher College.MallamTafawaBalewa, who later became the Prime Minister, soon joined the union. Though the union did not last long due to opposition from the Emir of Bauchi, it thus became the flagship of ethnic awakening in the north. In 1950, the Birom Progressive Union initiated the Middle Zone League (MZL) that agglomerated the Birom, Tiv, Idoma, Ilorin Yoruba, Nupe, Gwari, etc, protesting the endogenous domination of the core north. The mobilization was for members to speak with one voice. Southern minority groups like Edo National Union, and Ibibio State Union were also formed almost at the same time as the Ibo State union. The Ibibio State Union was a union for all Ibibio sub-groups and was the oldest all-tribal federation in Nigeria. Apart from being established for social reasons just like in the other parts of the country, the union was formed to address Yoruba and Igbo domination in the same way Middle Belt was.

Feeling of marginalization by the majority formed the basis on which common identity was constructed by the minorities in East and Northern Nigeria. Their transformation to militant unions was a consequence of the failure of post-colonial Nigeria to contain various challenges-insecurity, poverty, infrastructural decay, absence of good governance, political and sectarian violence, etc. Providing what the state would ordinarily have provided informed the subjective rationalization of militia sub-groups by scholars anchoring the debate on the theory of state fragility (Fukuyama 2004, Rotberg 2004, Chomsky 2006, Holsti 1996, Seddon 2002, Zeleza 2008, Mazrui 2008, Henderson 2008). This sordid situation in Nigeria raised an important question about the expected results of the nationalists' struggles for independence in Africa (Seddon 2002), and their failure to achieve confidence-building and class unity for the development of the continent rather than the civil wars and social violence (Zeleza 2008, Mazrui 2008, Henderson 2008) engulfing the continent. Social violence has created serious legitimacy crises and conflicts thereby inhibiting the state from providing for security regarded as the most important political goods (Rotberg 2004). As Fukuyama (2004) describes it, the state then lacks "stateness" that is, enforcement, the ultimate ability to send someone with a uniform and a gun to force people to comply with the state's law.

The illusory post-colonial State's inability to meet citizens' expectations resulted in the inmanifest domination of regional politics by ethnic militias. Groups like the O'odua People's Congress (OPC), the Gwama Boys formed by the Ilaje subethnic (Ilaje occupies majorly the coastal part of Ondo State) in 1998 in southwest Nigeria displayed actions of dissatisfaction with the Nigerian state. Expression of mere dissatisfaction with the governance structure transformed to open confrontation by the OPC after the annulment of the June 12 presidential election believed to have been won by Chief Moshood Abiola in1993. National Democracy Coalition (NADECO), and Afenifere (a Yoruba socio-cultural group), that emerged during the period provided the basis and impetus to OPC to act as a security network to police the entire southwest region and often demanding for self-determination (Osaghae, 1994, Agbu, 2004, Olorunfemi, 2007, Ajayi, 2007, Odoma, 2016). On their part, the Gwama Boys came up primarily to front a reprisal attack on the Ijaw sub-group who had taken the Ilaje by surprise in the wake of 1998. It was after this crisis that the Gwama Boys had a change of focus to address the marginalization of the Ilaje sub-group in the oildriven economy, quite similar to that of the emancipation of Niger Delta (MEND).

Southeastern Nigeria displays a kind of ethnic militias that are often blamed on the post-civil war policy of reconstruction, rehabilitation, and reintegration (3Rs) of the federal government (Ukaogo 2017). The Movement for the 
Actualization of the Sovereign State of Biafra (MASSOB) emerged in the year 2000 to express feelings of marginalization after what is referred to as the unprovoked and organized killing of Igbo people in some parts of Nigeria especially Northern Nigeria. Initially influenced by a philosophy of nonviolence, patterned after late Mahatma Gandhi, expressed in form of ordering Igbo people in any part of Nigeria to observe the annual sit-at-home order in support of the ideals of the movement, the distribution of Biafran currency, and encouragement of people to adopt it as a legal tender, compelling people to observe sanitation laws, gradually transformed to the establishment of military camps, paramilitary training of its members, sewing of Biafran military uniforms, the circulation of Biafran souvenirs such as stickers, umbrellas, belts, and almanacs earmarked the phase of pseudo militancy (Gilbert, 2004).

To borrow from what Maclean (2008: 166) referred to as "fighting locally, connecting globally", MASSOB established a "Biafra House" in Washington DC, United States, for the international coordination of its activities (WeeklyExpress, 2000). As asserted by the leader:

"Never shall we resolve to acquire inferior status in Nigeria out of cowardice. Nor shall we compromise the future of our children out of fear. It is more honorable to die in the struggle for freedom than to live as slaves. We have initiated the struggle for the emancipation of our people. It is a long-term project. God will provide the circumstance for the realization of our dream" Agbu (2004:21).

Indigenous People of Biafra (IPOB), a self-acclaimed defense of Igbo interest displays more militancy than MASSOB having engaged the Nigerian state in various forms. Nnamdi Kanu the IPO leader developed a more propagandist disposition from the onset having splintered from MASSOB. A belief among the members was that violence is the only language the Federal Government Nigeria understands, and only through it will the group be taken seriously (Thompson et al 2016). Deploying intense propaganda through radio and video broadcast, the Federal Republic of Nigeria is depicted as a zoo where the President is seen superintending the killings of other ethnic groups in which case the Federal Government declared IPOB a terrorist as a reaction to the group's demands (Ehikioya, 2017).

The militancy in the South-South area of Nigeria presents a rather more elaborate character in both theoretical discourse and empirical observation than any other part of the country. The region contributes more than $90 \%$ of the total oil revenue to the nation, thereby scaling up the region's relevance in Nigerian politics. Isaac Adaka Boro's declaration of the sovereign Ijaw nation to be called Niger Delta People's Republic in 1966 was the first attempt to different the SouthSouth area from the Southeast, which previously was known as Eastern Nigeria. The later development in which Isaac Boro joined the Nigeria army against the Biafran army during the Nigerian civil war shows that his grievance was against the Igbo neighbors considered to be the dominant ethnic group in the Eastern Nigeria in the same way Middle Belt League had grievances against Fulani/Hausa dominant group in the Northern Nigeria (Agbu 2004). South-South region comprises seven states of Edo, Delta, River, Bayelsa, Cross-River, and Akwa-Ibom, however, violence in the region is more endemic in River, Bayelsa, and Delta states.

Return to electoral democracy in 1999 in Nigeria opened political space for the sub-groups to release their bottled anger built up from military rule of over 36 years dominated by Fulani/Hausa hegemony that feasted on oil wealth (Siollun 2009, 2013). Isaac Adaka Boro's Niger Delta People's Republic ended with the death of the founder who lost his life during the Nigeria civil war of 1967-1970 fighting on the side of the Nigerian force. However, militia groups like the Movement for the Survival of Ogoni People (MOSOP), Ijaw Youth Congress (IYC), the Federated Niger Delta Ijaw Communities (FNDIC), Egbesu Boys of Africa (EBA), Niger Delta Peoples Volunteer Force (NDPVF), Niger Delta Strike Force (NDSF) and the Movement for the Emancipation of the Niger Delta (MEND) emerged to protest and defend the interest of the South-South zone of Nigeria for which Isaac Boro first agitated for albeit seeking for the separate state before the Nigerian civil war (Isumonah and Gaskia 2001). Fundamentally these ethnic militias agitated for resource control or favorable revenue sharing formula that would favor their areas (Amuwo et al 2004, Osaghae 2018). However, MEND (largely from Ijaw ethnic group) emerged as a reaction to the arrest, impeachment, re-arrest, detention, and trial of Dieprieye Alamieyeseigha, a former governor of Bayelsa, perceived by the people as a target because of his principled stance on resource control (Agbo, 2005). The tension remains tense because of the ecological challenges, poverty, and absence of economic development comparable to other regions despite contributing more than $90 \%$ of oil revenue. Containing the situation through Amnesty Program in 2009 by the federal government largely failed in dousing the tension as sounds of guns and artillery continue in the area coming majorly from Egbesu Boys of Africa (EBA), Niger Delta Peoples Volunteer Force (NDPVF), and Niger Delta Strike Force (NDSF) (Iwu et al 2013).

Northern Nigeria has the largest concentration of ethnic groups numbering 358 (Onwuejeogwu 1972). However, scholars have used Middle Belt and the core North as a frame of reference in differentiating political development in the region (Coleman 1986). Groups within Middle Belt emerged largely to contain the hegemonic tendencies of the Hausa/Fulani group that was rooted in pre-colonial rule (Tyoden 2000, Jibo et al 2001, Ochono 2014). These groups include the Middle-Belt Forum, Middle-Belt Progressive Movement (MBPM), Middle-Belt Patriots (MBP), MiddleBelt Youths Association (MBYA), and Association of Middle-Belt Academics (Agbu, 2004). The target of the groups has been to demand inclusion into the Northern hegemonic politics against other ethnic groups in Nigeria. 
The core North (the Hausa/ Fulani) has groups such as The Arewa People's Congress (APC), Arewa Consultative Forum (ACF), Arewa Youth Consultative Forum (AYCF), and recently Arewa Youth Assembly (AYA) (Shobayo 2021). Their formation was not in reaction to any perceived dominance but as a strategy to portray the core north as also having some demand to make on Nigeria state or as a signal that political power cannot be shared with other regions. Therefore formed on December 13, 1999, the Arewa People Forum (APC) was to mobilize support to checkmates the activities of the already existing O'odua People Congress in Western Nigeria, and any other threat that might erupt from ethnic-based militias (Agbu, 2004; CEDCOM 2003; Dike 2015). Sectarian groups like the Boko Haram in 2009 that operate under Islamic agenda, even the bandits in the north indisputably ${ }^{1}$ display actions that portray them as protecting the interest of the core north.

\section{ETHNIC MILITIAS AND DEMOCRATIC GOVERNANCE IN NIGERIA}

Democracy operates on the principle of equality, fairness, and accommodation of diversities of views. Expectedly it should move towards multi-party democracy that ensues pluralism contrary to single or dominant party democracy. Managing diversities under electoral democracy in Nigeria has countered serious challenges. Electoral democracies are what Schedler (1998:93) describes as subtypes of democracy that contain elements of liberal democracy and authoritarian rule, referring to them as semi-democratic regimes. Because elections are hotly contested, minority groups are merely incorporated under a pure patronage calculus by the dominant group(s) without any bargaining power. In this case, minorities lacking the political capacity to compete with the majority groups are alienated under a pretentious liberal democracy that is dominated by the elites from the majority ethnic group. This system portrays democracy in Nigeria as having a semblance of plural democracy. Plural democracy as argued by Lijphart (1977) has the best assurance of accommodating diversities in highly diverse societies under a consociational arrangement. A consociational arrangement according to Lijphart (1977: 5) is what Lehmbruch regards as "concordant democracy" defined as a strategy of conflict management by cooperation and agreement among the different elites rather than by competition and majority decision. The political elite's insistence on majority rule as against devising other accommodative strategies only perpetuates alienation of the minorities because of putting them on the fringe of political power. A deeply divided society can archive or pursue social homogeneity and political consensus regarded as a prerequisite for conducive and stable democracy (Lijphart 1977: 1), but in Nigeria, the political players and parties pretend to operate plural democracy but are manifestly laced

\footnotetext{
${ }^{1}$ This view became more pronounced after a prominent Muslim leader from the North canvassed that the bandits should be granted amnesty. www.vanguardngr.com $19^{\text {th }}$ Febuary 2021. Amnesty for bandits: PANDEF, Afenifere, Ohanaeze M-Belt leaders blast Sheik Gumi.
}

with liberal democracy. The hallmark of liberal democracy is open and free competition for power among individuals or groups who have equal rights. Contesting elections through a multi-party platform assumes that the groups or individuals have equal opportunities. This form of contestation poses danger in multi-ethnic societies where groups are not equal and the dominant groups that win under competitive elections dominate the weaker groups perpetually and candidates appointed from the minority groups under any federal arrangement are only proxies for the dominant groups. The proxy candidates appointed as compensation for acting as a cell for the dominant party are detached from his/her local people. The outcome results in ethnic militias emerging as a response to marginalization and suppression from the dominant groups.

Seeking confrontations against dialogue to balance political power emerges as a veritable approach because some of the measures that sustain the hegemony are structured into a constitutional document that takes on a rigid amendment process and has always been difficult especially when the contents of the constitution are in a favor of the dominant groups. Deploying violence by ethnic militias in this context should be seen as a means of communicating grievances (Abbink 2000, Aijmer 2000, Blok 2000) since violence is the only language government understands easily or rather hears in Nigeria.

Democratizing the State itself, political parties, engaging civil societies, and crosscutting alliances between ethnic militias are suggested as a means to discourage the emergence of ethnic militias or violent attacks against the state centers. The notion of democratizing the state in Nigeria implies forming a coalition of elites or what is referred to as a government of national unity (Osaghae 2018, Uroh 2004, Horowitz 1994). Politicians who operate on the principle of the zero-sum game, unfortunately, redistribute all sectors of the political space among themselves. Therefore, capturing the state becomes the fulcrum of the political game played by ethnic groups in Nigeria. Finding a favored partner from other ethnic groups by the political gladiators as an instrument of political patronage rather than for good governance and accountability becomes the finest approach and a proper political game. The citizens' expectations that the state should be efficient, effective, strong, capable of standing up to powerful global forces, efficient in the use of public resources, and effective in delivering the public good are rather jettisoned by policymakers.

State leaders in control of political parties preoccupy themselves with searching for a winning coalition (Dudley 1973) that produces a floating majority, which may create opportunities for the grafted politician from another ethnic group to occupy a political office one day. Rather than reduce tension this strategy fails, because the grafted politicians operate in the manner of local comprador suppressing and oppressing their fellows within their sphere of influence. This form of political arithmetic is have manifested between the 
Northern People's Congress (NPC) and National Congress of Nigerian Citizens (NCNC) (Osaghae 2002), and also embeds in intra-party arrangements in People's Democratic Party, All Progressive Congress (APC), etc, that compete for the state control in Nigeria's fourth republic. Democratizing the state under the patronage and clientelist (Nicolas van de 2007) or what Joseph (1987) referred to as prebendalism can only trigger or exacerbate resistance among discontented individuals or groups in the society. The discontented groups easily become a pawn to be drawn upon as a bargaining tool by the local or national politicians who want to ascend to become part of the same political arrangement that reproduces marginalization and unaccountable governance.

Soliciting for the civil societies as a panacea for the ills in the emerging democracies is an argument seen against the backdrop of their vibrant displacement of authoritarian governments in the former communist state when it rose in the 1970s and 1980s against the communist states of Europe, notably in Poland, Hungary, Czechoslovakia and Yugoslavia manifesting in the collapse of communism in Eastern Europe. Diamond (1994) argues that in this third wave of global democratization no phenomenon has more vividly captured the imagination of democratic scholars, observers, and activities alike than "civil society." What could be more moving than the stories of brave bands of students, writers, artists, pastors, teachers, laborers, and mothers challenging the duplicity, corruption, and brutal domination of authoritarian states? Could any sight be more awe, inspiring to democrats than the one they saw in Manila in 1986, when hundreds of thousands of organized and peaceful citizens surged into the streets to reclaim their stolen election and force Ferdinand Marcos out through non-violent means, "people power?" This paper strongly calls for the spirit of fellow feeling in Nigeria to close the centrifugal political culture that results in ethnocentric politics, corruption, and conflicts. The 'state of Nigeria' as created by the colonialist needs to be transformed to 'Nigerian state' championed by civil societies against the despotic governments that alienates them. A common nationality of citizens comprising of local, ethnic, and professional bodies united in public opinion could muzzle power against the structured imbalance created by the government under this semi-democratic federal arrangement.

Opinion can be canvassed for bridges that can unite different ethnic militias such that OPC and Egbesu boys or IPOB and MBYA could form a common opinion against Nigerian political leaders irrespective of ethnic origin. A truce reached after the bloody clash between OPC and AYCF in Lagos is cited as an indication that ethnic militias may not be opposed to each other (Sesay., Ukeje, Aina, and Odebiyi, 2003). This short-term measure that calmed the tension between the Yoruba and Northern youths over business infringement cannot be a strategy that can stamp out the disruptive nature of ethnic militias in democratic governance in Nigeria. It is certainly going to be a hard nut to crack because these ethnic militias are formed, financed, and serves as an instrument of bargaining by the political gladiators who use them to confront internal or external oppositions. To allow a coalition or alliances of ethnic militias such that OPC and Egbesu boys or IPOB and MBYA or the recent scenario where Middle Belt Youths is showing sympathy for southern ethnic groups (Shobayo 2021) etc, is certainly expected that they can even topple the political leaders since they bear the weapons on behalf of their ethnic godfathers. In the context of power relations and political followers, political gladiators would avoid any game that would displace their status quo, therefore such instrumental 'marriage' between and among ethnic militias cannot be tolerated by the gladiators (Milbrath 1965, Deutsch 1974, Dahl 1976, Weir 1999).

In the same vein, calling for a dialogue between the ethnic militias and the Nigerian government is often construed as confirmation of the weakness of the State institutions under a simple logic that the State has simply alluded to the more firing or superior ammunitions of the ethnic militias. The transition from military to democratic governance in $2009 \mathrm{did}$ not transform to institutionalizing democratic values suggestive of widely accepted norms of democracy. Transiting from authoritarian rule and deploying the same approach in the conduct of the election is so obvious in Nigeria. Ethnic militias thrive under electoral democracies that are concerned about periodic elections and not bothered if candidates are imposed on the electorates or not. The violence that occurs during the elections is an indication of the prime use of ethnic militias either to outwit local opponents and or to intimidate opponents from other ethnic groups. The editor of the Tell Magazine (2019: 13) capturing the scenario in an article titled 'the shame of a nation' wrote that we believe that politicians, either in the opposition or the ruling party, the elite, and the electorate are culpable in the conspiracy to draw us backward. In the same vein, Obe (2019:33) captures the scene of the presidential election in Rivers State describing it as a "rivers bloody election". This situation points to relapse to authoritarianism from electoral democracy contrary to the expectation that the transition will continue from authoritarian rule to electoral democracy and upwards to liberal and advanced democracy.

Schedler (1998:93) included the notion of "clean" as an element among the properties of electoral democracy. The notion of "clean" as referred to by the author does not exist in the electoral contest in Nigeria. We cannot attribute 'clean' to elections that always accompany bloodshed. In that case, we align more with Schedler's later description of electoral democracy as a "diminished subtype" of democracy. Aptly referred to as a diminished subtype or semi-democratic regimes separates electoral democracies characterized by violence and impositions of candidates from liberal democracy, which Dahl (1971) identified as engendering civil and political rights plus fair, competitive, and inclusive elections called "polyarchies". Return to democratic rule in 1999 and the electoral victory of Rtd. General Olusegun Obasanjo as Albert (2011) argues, indicates a mere compensation to Southwestern Nigeria, whose son was denied emerging as president having won the presidential election in 
1993, believed to be free and fair and also to reward him for supporting the Northern political elites that ensured that a Northerner emerged as president in 1979 election. The success of mobilizing local supporters is often anchored on the use of the local militias to intimidate and even to 'kill individuals standing on their way' as commonly known in Nigeria's politics. Albert (2011: 17) aptly posits that:

One way in which politicians have used election seasons to endanger Nigeria's national security in the past is the recruitment of political thugs. This is a nationwide problem with 2003 in the Niger Delta providing the worstcase scenario. The thugs recruited by the politicians in the region for this election were the people that later took up arms against the Nigerian state. In many parts of southwestern Nigeria, politicians also made effective use of members of the Nigerian Union of Roads Transport Workers (NURTW) and in the process, many lives were lost during the 2007 elections particularly.

The presidential election of 2011 exemplified this gory and terrific situation, taking away the lives of some serving five members of the National Youths Service Corps (NYSC). Many others were killed by motor accidents in an attempt to escape from the Northern part of Nigeria including destructions of properties as a protest that a candidate from south-south Nigeria emerged as president and not from northern Nigeria. Thisbitternesswas reflected in the warning later issued by General Rtd. Mohammad Buhari, the main opposition party flag-bearer from northern Nigeria in the 2015 election, when he warned that "if what happened in 2011 should again happen in 2015, by the grace of God, the dog, and the baboon would all be soaked in blood" (Binniyat 2012). The post-2015 election and the emergence of an incessant and murderous attack by the bandits in the northern till date raised critiques that these bandits were the ones armed to be unutilized as political thugs should a southerner emerge as a winner in the 2015 election but abandoned since the earlier warning and intimidation produced the expected ends.

This assumption can be established against the backdrop of the responses from some northern leaders regarding the level of insecurity caused by bandits, thereby raising some worry warranting the demand by southwestern governors asking the federal government under the leadership of northern political leaders to prove to other Nigerians that they are not supporting criminality in Nigeria (Johnson, Akinrefon, Nwabughiogu, and Badru 2021). The query is one of the many reactions against their defense of the bandits which others see as an instrument for political bargaining. Ramon (2021: 37-38) captures this assumption from the response by Sheikh Abubakar Gumi, an influential Islamic cleric from the north who argues that governors opposing amnesty for the bandits shouldn't be taken seriously. Stressing, the bandits are not different from Niger Delta militants or Indigenous Peoples of Biafra (IPOB). This seemingly intractable problem we argue can only be tackled by civil society's unifying effort to compel governments to accountability and good governance.
However, they are stifled by a lack of financial base, which predisposes them to manipulation by the political class. There could be a problem also relying on foreign donors for finances to operate which often may be in short supply or the issue for which the funds are demanded may not attract the interest of the donors (Makumbe 1998, Nwabueze 1993, Kew 2009, Iwu 2010, Obadare 2011). This is not to say that civil society will neglect their primary role of keeping the state under even when funding is their major problem and also through concerted mobilizations are to confront the activities of some ethnic militias whose aim is to pull down the state.

Certainly, the centrifugal politics that pervaded immediate post-colonial politics of Nigeria continues to shape the contours of politics almost three decades after independence. Politicians have consistently drawn from ethnolinguistic symbols to mobilize their members for political space. The problem that emerges is that the incorporation of their ethnic unions that take the form of civil societies to occupy political leadership or gaining access to resource distribution raises questions about civil society and social capital and the civility of the civil societies. The question becomes pertinent as the civil societies are expected to mediate over a problem in which their neutrality is suspicious. This is a complex question that civil society theorists have tried to address (Markovitz 1988, Bob 2011, Young 1994, Bratton 1994, Azarya 1994, Diamond 1997). These authors raised the important issue of if the state and society exist independently in Africa and concluding that both intertwine in complex, changing ways. As argued, elements of civil society are not merely affected by the state but are seated in the state. This is not just a question of a few representatives of the elites sitting in parliamentary assemblies; it is a problem of embeddedness, of establishing and of realigning networks (Markovitz 1988: 22).

The questions become apparent because of the personalistic rule that narrows political space in favor of the ethnolinguistic group that occupies the seat of government. Reno (2004:220) captures the position of Obafemi Awolowo's notion of mobilization of his ethnic group where he wrote that Awolowo the mid-twentieth century Yoruba nationalist leader held the view that ethnolinguistic groups were an appropriate basis for politics. In the presence of economic decline arising from corruption, other members of the society excluded from the mainstream governance perceive the praetorian leader as an object that must be resisted with violence. Therefore, mobilizing ethnic unions, religious bodies or ethnic militias emerge as the option as a counterforce. Often some institutions are created to accommodate supporters of the government and even to extend the incorporation of some members of the opposing ethnic unions. For example, Better Life for Rural Women Programme under Babangida in 1985 chaired by his wife, Department for Rural Roads and Infrastructure, Bureau for Mass Mobilization, Family Economic Advancement Programme that succeeded in attracting \$1.2 million World Bank finance for investment in microenterprise for poverty alleviation under Abacha regime 
in 1997, and the Association for Better Nigeria (ABN) championed by former senator Arthur Nzeribe turned out to be a scam to settle political cronies. Reno (2004: 221-222) cited a statement made by Senator Arthur Nzeribe regarding the prevailing situation in Nigeria who said that "if everybody was corrupt, he would be a fool to be an exception to the prevailing rot and malaise."

These situations point to the reason for mobilizing ethnic militias and the demands they make in seeking to be part of the looting team in government (Iwu 2010), which in turn reproduces a spiral of underdevelopment. There is a debate if these ethnic unions including ethnic militias can be included as part of civil society. Following this line debate, a group can easily be accepted as a civil society if it builds reciprocity and trust across primordial divisions such as ethnic and racial lines (Tocqueville 2004, Putnam 2001). As Bob (2011: 210-213) puts it, many societies especially during their formative years had many groups that can be classified as uncivil societies because they were used for specific purposes. Nazi Germany, Maoist China, including numerous associations in America in the early nineteenth century were regarded as atomistic and conflictual, and in Japan where the government deliberately encouraged small local organizations while inhibiting others thereby creating dual civil society were cited as examples. These associations were used to entrench government or ruling class in power against collective will because of their exclusionary and belligerent activities. The problem is that Nigeria's political leaders have continued to rely on ethnolinguistic symbols several years after independence ignoring nation-building that can serve as an efficient conflict resolution mechanism.

\section{CONCLUSION}

The emergence of ethnic militias as a response to a faulty political system remains a major threat to democratic governance in Nigeria. Government approaches the issue of governance rather than breeds more troubles because of frustration arising from disregard for inclusive governance and accountability. The phenomenon resulted in the use of ethnic militias as bargaining tools by both local and national political elites seeking to occupy political positions. Transiting from authoritarian rule to democratic governance in 1999 raised the hope that Nigeria will not stop at electoral democracy but move on to liberal and advanced democracy. This belief is dashed as the hegemonic ethnic groups rather than operate an inclusive and accountable government uses their ethnic militias as an instrument of intimidation and manipulation of political elites from other ethnic groups. As the problem appears intractable, civil societies believed to have persuasive and unifying capacity because of its crosscutting memberships and distaste for bad governance are having a problem maintaining autonomous existence from the state because of lack of financial base resulting in seeking funds from the same political class it was supposed to keep in check. However, we argue that despite challenges against civil societies in Nigeria, it possesses an important attribute because they can easily forge a consensus against the political leaders as the government uses more of a stick than a carrot against their members. This sense of externality and opposition to the state is germane to save Nigeria from total collapse and the level of insecurity emanating from the activities of ethnic militias. The paper submits that though civil society cannot be absolved from state control in certain circumstances, yet it still emerges as a panacea for most of the societal ills because its ultimate goal is to create social capital and cross-cutting cleavages, and their successes in holding despotic government are well documented (Harbeson et al 1994, Edwards 2011, Kasfir 1998).

\section{REFERENCES}

[1] Abbink, J. (2000). Preface, "Violation and violence as a cultural phenomenon", in Göran Aijmer and Jon Abbink, Meaning of Violence: A Cross-Cultural Perspective, xi-xvii. Oxford: Berg

[2] Abrahms, M. (2005). What terrorists really want. International Security 32(4): 78-105

[3] Agbo, A. (2005). The trial of a Jesus: Citing selective justice and political vendetta on the part of President Olusegun Obasanjo, some Ijaws stand resolutely behind governor Dieprieye Alamieyeseigha, aka 'Jesus of the Ijaws', accused by some at home of corruption and charged abroad for money laundering. Tell Magazine No. 40 October 3.

[4] Agbu, O (2004). Ethnic Militias and the Threat to Democracy in Post-Transition Nigeria. Research Report No 127, NordiskaAfrikainstitutet,. Uppsala

[5] Aijmer, G. (2000) "Introduction: The idiom of violence in imagery and discourse", in Göran Aijmer and Jon Abbink, Meaning of Violence: A Cross-Cultural Perspective, 1-22. Oxford: Berg

[6] Ajayi, J.O. (2007). Oodua Peoples' Congress (OPC) and Crime Control in the Lagos Metropolis. A Thesis in the Department of Sociology, Submitted to the Faculty of Social Sciences, In partial fulfillment for the Degree of Doctor of Philosophy, University of Ibadan, Nigeria.

[7] Albert, I. O. (2011). "Elections and State fragility in Nigeria's fourth republic" in Isaac O. Albert, Nathaniel L. Danjibo, Olusola O. Isola and Stephen A. Faleti (eds), Democratic Elections and Nigeria's National Security. Ibadan: John Archers Publishers

[8] Amuwo, K., Adigun, A. B. A., Suberu, R. T., and Hérault, G. (2004). Federalism and political restructuring in Nigeria. Ibadan: Spectrum Books Limited

[9] Azarya, V. (1994). Civil society and disengagement in Africa, in Harbeson, J. W., Rothchild, D., and Chazan Naomi (ed.). Civil Society and the State in Africa. London: Lynne Rienner, 83-102

[10] Binniyat, L. (2012). "If what happens in 2011 should again happen in 2015, by the grace of God, the dog, and the baboon would all be soaked in blood". www.vanguardngr.com. Accessed 19/03/2021

[11] Blok, A. (2000). "The enigma of senseless violence", in Göran Aijmer and Jon Abbink, Meaning of Violence: A Cross-Cultural Perspective, 23-38. Oxford: Berg

[12] Bloom, M. (2005). Dying to kill: The allure of suicide terrorism. New York: Columbia University Press

[13] Bob, C. (2011). "Civil and uncivil society", in Michael Edwards (ed). The Oxford Handbook of Civil Society. New York: Oxford University Press, pp 209-219

[14] Bratton, M. (1994). Civil society and political transition in Africa, in Harbeson, J. W., Rothchild, D., and Chazan Naomi (ed.). Civil Society and the State in Africa. London: Lynne Rienner, 51-82

[15] Center for Development and Conflict Management Studies (CEDCOMS). (2003). Ethnic Militias and The Future of Democracy in Nigeria. Ile-Ife: Obafemi Awolowo University Press

[16] Chomsky, N. 2006. Failed states, the abuse of power, and the assault on democracy. The American empire project. Metropolitan Books. 
[17] Coggins, B. L. (2015). Does state failure cause terrorism? An empirical analysis (1999-2008). Journal of Conflict Resolution $59(3) 455-483$

[18] Coleman, J. S. (1986). Nigeria: Background to nationalism. Benin City: Broburg \&Wistrom.

[19] Dahl, R. (1971). Polyarchy: Participation and opposition. New Haven: Yale University Press

[20] Dahl, R. (1976). Modern political analysis. New Jersey: PrenticeHall

[21] Deutsch, K. W. (1974). Politics and government: How people decide their fate. Boston: Houghton Mifflin Company

[22] Diamond, L. (1997). Civil society and democratic consolidation: Building a culture of democracy in a new South Africa, in Rukhsana A. Siddiqui (ed.), Subsaharan Africa in the 1990s: Challenges to Democracy and Development. Westport, CT: Praeger, 3-23

[23] Diamond, L. 1994. Rethinking Civil Society towards Democratic Consolidation. Journal of Democracy 21(2).

[24] Dike, E. O (2015). "Insecurity and Civil Society Response in Nigeria: A Historical Perspective and its Implications for Peace and Development". African Research Review, Vol 9, No 4, pp $110-122$

[25] Dudley, B. J. (1973). Instability and political order: Politics and crisis in Nigeria. Ibadan: Ibadan University Press

[26] Edwards, M. (2011). The Oxford Handbook of Civil Society. Oxford: Oxford University Press

[27] Ehikioya, A. (2017). "Federal Government Slams France, UK Roles in IPOB Crisis - High Court Proscribes IPOB." The Nation, September 21

[28] Finer, S. (1966). The anonymous empire. London: Paul Mall

[29] Fukuyama, F. (2004). State building, governance, and world order in the twenty-first century. London: Profile Books LTD

[30] Gilbert, L. D (2013) "Ethnic Militancy in Nigeria: A Comparative Re-appraisal of Three Major Ethnic Militias in Southern Nigeria". Journal Of Humanities And Social Science, Vol 17, No 6

[31] Gowon, Y. and Effiong, O. P. (2001). The Nigerian civil war and its aftermath: Views from within. Ibadan: Programme on Ethnic and Federal Studies (PEFS). Occasional Paper No.1

[32] Harbeson, J. W., Rothchild, D., and Chazan Naomi (ed.), (1994). Civil society and the state in Africa. London: Lynne Rienner

[33] Henderson, E. A. (2008). "When States implode: Africa civil wars 1950-1992", in Alfred Nhema and Paul Tiyambe Zeleza (eds). The Roots of African Conflicts: The Causes and Costs. Uk: James Currey Ltd, pp 51-70

[34] Holsti, K. J. 1996. The state, war, and the state of war. Cambridge: Cambridge university press.

[35] Horowitz, D. L. (1994). "Democracy in divided societies", in L. Diamond and M.F. Plattner (eds), Nationalism, Ethnic Conflicts, and Democracy. Baltimore \& London: John Hopkins University Press

[36] Isumonah, V. A., and Gaskia, J. (2001). Ethnic groups and conflicts: The SouthSouth zone of Nigeria. Ibadan: The Lord's Creations

[37] Iwu, H. N. (2010). "Leadership and Good Governance: Civil Society Perspective" Africa: Journal of Contemporary Issues, 8, (8). 32-44

[38] Iwu, H. N., and Oko, C. O. (2013). Amnesty and the question of national security: the case of Boko Haram in Nigeria. In A. Sesan Ayodele, Ibiyinka O. Solarin, \& Taiwo S. Adenegan (eds) Nigeria's socio-economic and political dilemmas: the challenges and the way out. Proceedings of the $1^{\text {st }}$ Achievers National Conference on Public Policy. Ibadan, Intanitina G M Publishers, 140-153

[39] Iwu, H.N. (2010). Beyond the eagle eyes of EFCC. In Anowai, E.C (ed.) Corruption: The bane of Nigeria's development. Publication by Pope John Paul 11 Annual Memorial Lecture Series. (6). Major Seminary Akwa, Anambra State. 204-226.

[40] Jibo, M., Simbine, A. T., Galadima, H. S. (2001). Ethnic and conflicts in Nigeria: The Northcentral zone of Nigeria. Vol. 4. Programme on Ethnic and Federal Studies (PEFS).
[41] Johnson, D., Akinrefon, D., Nwabughiogu, L., and Badru, D. (2021). Insecurity: Prove to Nigerians you don't support criminality, Southwest governors tell FG. Vanguard Newspaper. 27. No. 64273

[42] Joseph, R. (1987). Democracy and prebendal politics in Nigeria: The rise and fall of the second republic. Ibadan: Spectrum Books

[43] Kant, I. (1795). "Perpetual peace", repr, in H. Reiss (ed), Kant's Political Writing. Cambridge: Cambridge University Press (1992), 93-131

[44] Kasfir, N. ed. (1998). Civil society and democracy in Africa: Critical Perspectives. London: Frank Cass.

[45] Kew, D. "Democratizing Donor-Civil Society Relations: Evidenced from Governance Programs in Nigeria" in Richard Joseph and Alexandra Gillies, Eds. Smart aid for African development. Boulder: Lynne Rienner Publishers, 2009. 207-227

[46] Lijphart, A. (1977). Democracy in plural societies: A comparatives exploration. New Haven and Yale University Press

[47] Maclean, S. J. (2008). "Fighting locally, connecting globally: Inside and outside dimensions of African conflict", in Alfred Nhema and Paul Tiyambe Zeleza (eds). The Roots of African Conflicts: The Causes and Costs. Uk: James Currey Ltd, 166-180

[48] Makumbe J. Mw. (1998). "Is There Civil a Society in Africa?"International Affairs 74, (2) 305-317.

[49] Markovitz, I. L. (1998). Uncivil society, capitalism and the state in Africa, in Nelson Kasfir (ed), Civil SOCIETY AND Democracy in Africa: Critical Perspectives. London: Frank Cass, 21-53.

[50] Mazrui, A. A. (2008). "Conflicts in Africa: An overview", in Alfred Nhema and Paul Tiyambe Zeleza (eds). The Roots of African Conflicts: The Causes and Costs. Uk: James Currey Ltd, pp 36-50

[51] Nicolas van de. W. (2007). "Meet the new boss, same as the old? The evolution of political clientelism in Africa" Patrons, in Herbert Kitschelt and Steven I. Wilkinson (eds). Patrons, Clients, and Policies: Patterns of Democratic Accountability and Political Competition. New York: Cambridge University Press, 50-67

[52] Niven, C. R. (1958). How Nigeria is governed. London: Longmans, Green, and $\mathrm{CO}$

[53] Nnoli, O. (1978). Ethnic politics in Nigeria. Enugu: Fourth Dimension Publishers

[54] Nnoli, O. ed. (1998). Ethnic Conflicts in Africa, Dakar: CODESRIA Books.

[55] Nwabueze, B. O. (1993). "A Virile Civil Society," in Democratization. Spectrum Law Publishing, 84-91

[56] Obadare. E. (2011). "Civil society in Sub-Saharan Africa," in The Oxford Handbook of Civil Society ed. Michael Edwards. Oxford: Oxford University Press, 183-196.

[57] Obe, E. (2019). Rivers bloody election: Presidential election in Rivers State records high casualties raising fears about future elections and the safety of the people. Tell Magazine/ March 11, No. 10

[58] Ochono, M. E. (2014). Colonialism by proxy: Hausa imperial agents and Middle Belt Consciousness in Nigeria. USA: Indiana University Press

[59] Odoma, U. S (2016)."Democratic Practice and Development of Ethnic Militias in Nigeria".Pyrex Journal of Political Science and International Relations, Vol 10, No 10

[60] Olorunfemi J. O. (2007). "Ethnic Militia, National Security and Roles of the Nigerian Armed Forces in Democracy: Niger Delta Crisis in Perspective" Nigerian Army Quarterly, 2:1, 22-38.

[61] Onwuejeogwu, M. A. (1972). The multi-ethnic nationalities of Nigeria and the problems of governance. Ibadan: Institute of Affrican Studies

[62] Osaghae, E. E. (2002). Crippled giant: Nigeria since independence. Ibadan: John Archers Publishers

[63] Osaghae, E. E. (2018). "Democracy and national cohesion in the multi-ethnic African States: South Africa and Nigeria compared", in Eghosa E. Osaghae. Transitions, Democratic Process, and Political Stability: Perspectives on African Politics, Governance, and Development. 91-120. Ibadan: BookCraft 
[64] Osaghae, E. E. (2018). Ethnicity, ethnic politics, and ethnic nationalism: Perspectives on African Politics, Governance, and Development. Ibadan: BookCraft

[65] Osaghae, E., (1998). "Managing Multiple Minority Problems in a Divided Society: The Nigerian Experience".Journal of Modern African Studies, No. 36.

[66] Osaghae, E.E. (1994). Ethnicity and its Management in AfricaThe Democratic Link. Lagos: Malthouse Press Ltd

[67] Otite, O (2000). Ethnic Pluralism Ethnicity and Ethnic Conflicts in Nigeria. Ibadan: Shaneson C I. Limited $\left(2^{\text {nd }}\right.$ ed $)$

[68] Putnam, R. D. (2001). Bowling alone: The collapse and revival of American community. New York: Simon and Schuster

[69] Ramon, O. (2021). Governors opposing amnesty for the bandits shouldn't be taken seriously. Sunday Punch. 25. No. 20, 140

[70] Reno, W. (2004). The root of sectarian violence and its cure, in Robert I. Rotberg (ed.), Crafting the New Nigeria: Confronting the Challenges. Lodon: Lynne Rienner, 219-238 Tocqueville, A. (2004).,(1835, 1840). Democracy in America. Trans A. Goldhammer. New York: Library of America.

[71] Rotberg, R. L. 2004. The failure and collapse of Nation-State: breakdown, prevention, and repair, in R. I. Rotberg (ed) when states fail: causes and consequences. Princeton: Princeton university press.

[72] Schedler, A. (1998). What is democratic consolidation? Journal of Democracy, (9). 2.

[73] Seddon, D. (2002). Popular protest and class struggle in Africa. In Leo Zeilig (ed). Class Struggle and Resistance in Africa. Chicago: Haymarket Books, pp 57-87

[74] Sesay, A., Ukeje, C., Aina, O., and Odebiyi, A. (2003). Ethnic militias and the future of democracy in Nigeria. Ile-Ife: Obafemi Awolowo University Press

[75] Shobayo, I. (2021). Arewa youths quit notice to North-based Yoruba a ploy for anarchy-Middle Belt Youths. Sunday Tribune, March 21. No. 2,299

[76] Siollun, M. (2009). Oil, politics, and violence: Nigeria's military coup culture 1966-1976. New York: Algora Publishing

[77] Siollun, M. (2013). Soldiers of fortune: Nigerian politics from Buhari to Babangida 1983-1993. Abuja: Cassava Republic Press
[78] Smith M. G. (1965). The Plural Society in the British West Indies. University of Califonia Press

[79] Tell Magazine (2019). The shame of a nation. Editorial. March 11, No. 10

[80] Thompson O.O, Ojukwu C.C, Nwaorgu, O.G.F (2016). "United We Stand, Divided We Fall: Resuscitation of TheBiafran State Succession and The National Question Conundrum", Jorind Vol.14, No. 1

[81] Tyoden, S. G. (2000). The Middle Belt and Nigeria politics. Jos: AHA Publishers Limited

[82] Ukaogo, V. (2017). Gowon's three R's and Yar'Adua's General Amnesty: An analysis of policy failures, security challenges and consequences in the West African Atlantic Seaboard. https://www.researchgate.net/publication/338739945_Gowon's_Th ree_R's_and_Yar'Adua's_General_Amnesty_an_Analysis_of_Poli cy Failures Security Challenges and Consequences in the We st_African_Atlantic_Seaboard. Accessed 15/02/2021

[83] Uroh, C. O. (2004). "On the ethics of ethnic balancing in Nigeria: Federal character reconsidered", in Kunle Amuwo, Adigun Agbaje, Rotimi Suberu, and Georges (eds). Federalism and Political Restructuring in Nigeria, 191-200. Ibadan: Spectrum Books

[84] Varshney, A (2002). Ethnic conflict and civic life: Hindus and Muslims in India. London: New Haven and Yale University Press

[85] Weekly Express (2000). "MASSOB Leader Released", Vol. 1, No. 7.

[86] Weir, S. (1999). "Participation and passivity: No room at the top", in David Campbell and Douglass Lewis (eds), Promoting Participation: Law or Politics. London: Cavendish Publishing Limited, 101-112

[87] Young, C. (1994). In search of civil society, in Harbeson, J. W., Rothchild, D., and Chazan Naomi (ed.). Civil Society and the State in Africa. London: Lynne Rienner, 33-50

[88] Zeleza, P. T. (2008). "The causes and costs of war in Africa: From liberation struggles to the war on terror", in Alfred Nhema and Paul Tiyambe Zeleza (eds). The Roots of African Conflicts: The Causes and Costs. Uk: James Currey Ltd, pp 1-35 